Check for updates

Cite this: RSC Adv., 2018, 8, 20222

\title{
A study on a telo21 G-quadruplex DNA specific binding ligand: enhancing the molecular recognition ability via the amino group interactions $\dagger$
}

\author{
Dongli Li,,$^{\mathrm{ab}}$ Jin-Qiang Hou, $\$^{\mathrm{c}}$ Wei Long, ${ }^{c}$ Yu-Jing Lu, ${ }^{\mathrm{bc}}$ Wing-Leung Wong (D) *ab \\ and Kun Zhang ${ }^{\star a b}$
}

A symmetric ligand is synthesized composed of a core $\mathrm{N}$-methylpyridinium scaffold and two parasubstituted benzyl groups through a flexible ethylene bridge to form a novel three-ring-conjugated system. The ligand system was found to have only weak background fluorescent signal in aqueous or physiological conditions and exhibited strong fluorescent signal enhancement targeting at telo21 Gquadruplex structure rather than other types of nucleic acids. The comparison study with two terminal groups $\left(-\mathrm{N}\left(\mathrm{CH}_{3}\right)_{2}\right.$ versus $\left.-\mathrm{SCH}_{3}\right)$ indicates that the stimulated signal enhancement of specific binding is probably attributed to the hydrogen-bonding interactions through the amino groups in the G-quartets. The docking result illuminates the experimental observation that the ligand system showed only weak fluorescent signals in aqueous or physiological conditions while exhibiting a strong fluorescent signal upon binding to the telo21 G-quadruplex structure (binding energy: $-6.2 \mathrm{kcal} \mathrm{mol}^{-1}$ ).

Received 4th May 2018

Accepted 27th May 2018

DOI: $10.1039 / \mathrm{c} 8 \mathrm{ra03833c}$

rsc.li/rsc-advances native environment is still challenging. ${ }^{13,14}$ In the nucleic acid research area, to discrimination of G-quadruplex (G4) structures from other type of DNA by visual methods is a big difficulty. ${ }^{15-17}$ For this reason, considerable efforts are in progress for the discovery of quadruplex specific binding ligands endowed with fluorescence properties.

Diverse molecular design is recognized as a right strategy to search for G4-selective molecular fluorescent probes or ligands that display a strong enhancement upon binding with G4DNA. ${ }^{18-20}$ Our recent study demonstrated that the small organic molecular ligand system is also able to achieve excellent Gquadruplex DNA selectivity with the induction of a strong fluorescent signal against other DNA tertiary structures. ${ }^{21} \mathrm{~A}$ crucial factor of the design reported is to build a $\pi$-conjugated co-planar two-ring system with a slightly rotatable ethylene bridge that increases the structural flexibility of the molecule (Fig. 1, L) ${ }^{22}$ The reported ligand $\mathbf{L}$ shows only limited signal discrimination ability although its signaling specificity towards G4-DNA is merit. Probably due to the ligand only has one amine group for interaction. To further advance the structure design, in the present study, a symmetrical ligand with $N, N$-dimethylaniline groups was constructed based on the $\pi$-conjugated coplanar three-ring system framework and investigated the significance of the presence of two amino groups in enhancing the interaction signaling through the comparison with a nonpolar analog (methylthio group). The results indicated that the two amino groups provide extra binding affinity and selectivity towards telo21 G4-DNA, which is most probably attributed 
<smiles>[R]c1ccc(/C=C/c2cccc(/C=C/c3ccc([R])cc3)[n+]2C)cc1</smiles>

$1 \mathrm{R}=\mathrm{N}\left(\mathrm{CH}_{3}\right)_{2}$

$2 \mathrm{R}=\mathrm{SCH}_{3}$<smiles>C[n+]1ccccc1/C=C/c1c[nH]c2ccccc12</smiles>

$\mathbf{L}$

\section{Conjugated two-ring system}

Fig. 1 Chemical structures of the fluorescent nucleic acid binding ligands.

Table 1 The spectroscopic properties of nucleic acid binding ligands

\begin{tabular}{|c|c|c|c|c|c|c|}
\hline Ligand & Side group & $\lambda_{\mathrm{Abs}, \max }{ }^{a}(\mathrm{~nm})$ & $\lambda_{\mathrm{ex}}{ }^{a}(\mathrm{~nm})$ & $\lambda_{\mathrm{em}}{ }^{a}(\mathrm{~nm})$ & $\Phi_{\mathrm{f}}^{b}$ & $K^{c}\left(\times 10^{5} \mathrm{M}^{-1}\right)$ \\
\hline 1 & $\mathrm{R}=\mathrm{N}\left(\mathrm{CH}_{3}\right)_{2}$ & 450 & 460 & 580 & 0.05 & $1.44 \pm 0.35$ \\
\hline 2 & $\mathrm{R}=\mathrm{SCH}_{3}$ & 402 & 402 & 530 & 0.02 & $1.18 \pm 0.21$ \\
\hline
\end{tabular}

${ }^{a}$ Experiments were performed in $10 \mathrm{mM}$ Tris-HCl buffer at $\mathrm{pH} 7.4 .^{b}$ Relative fluorescence quantum yield of probes upon addition of $3 \mu \mathrm{M}$ telo21, standard of the relative fluorescence quantum yield is fluorescein $\left(\Phi_{\mathrm{f}}=0.85\right.$, in $\left.1 \% \mathrm{NaOH}\right) .{ }^{c}$ Equilibrium binding constant between the ligand and telo21 DNA.

to the extra hydrogen bonds formed with the hydroxyl groups in groove structure of telo21. ${ }^{23}$ FRET melting experiments also support the amino groups granting an extra stabilization for the G-quadruplex structure of telomeric DNA.

\section{Results and discussion}

The new nucleic acid binding ligand targeting at human telo21 G-quadruplex DNA was synthesized by the piperidine-catalyzed Knoevenagel condensation reaction using 1,2,6trimethylpyridin-1-ium iodide and para-substituted benzaldehyde, for examples $p$-(dimethylamino)benzaldehyde and $p$ (methylthio)benzaldehyde, as the reactants in $n$-butanol under reflux conditions. Pure compounds of 1 and 2 shown in Fig. 1 were obtained by re-crystallization from acetone with $70-85 \%$ yields.

The spectroscopic properties of the nucleic acid binding ligands were listed in Table 2. The ligand with $N$-methylpyridinium scaffold as the core that is fused to form a three-ringconjugated system exhibited absorption maxima at $402 \mathrm{~nm}$ and $450 \mathrm{~nm}$ and shows very weak emission signal in the range of 530-580 $\mathrm{nm}$ in aqueous buffer solution at $\mathrm{pH}$ 7.4. Interestingly, when addition of various nucleic acids such as those examined herein with the single-stand DNA: dA21, duplex DNA: ds26, G-quadruplex DNA: telo21, and RNA, the ligand was able to induce different degrees of fluorescent signal at yellow-green region (1: $\lambda_{\text {em }}=580 \mathrm{~nm}$ ) as shown in Fig. 2 . The difference in the fluorescent intensity observed indicates a recognition ability of the ligands towards different types of DNA structure. Particularly, ligand 1 upon binding human telo21 G-quadruplex DNA showing the highest emission signal while other types of DNA including RNA, dA21, and ds26 show very weak recognition response. However, its analog ligand 2 has no such distinctive recognition observation when tested with different nucleic acids under the same conditions. This could conclude that the side groups (dimethylamino versus methylthio) of the binding ligands take a significant effect on the fluorescent recognition of different type of nucleic acids structures. We speculated that the dimethylamino group is polar and is able to offer extra hydrogen bonds formation with the hydroxyl groups in groove structure of telo21 G4-DNA structure while the methylthio group has no such character. This explanation is further supported by the results obtained in the binding kinetics study and FRET melting experiments.

The molecular binding kinetics of the ligand with nucleic acids could be able to demonstrate the interaction difference due to dimethylamino and methylthio side group of the ligand. Fig. 3 showed the ligand binding assays at equilibrium, obviously the binding ligand with dimethylamino group showed much stronger recognition and interaction emission signal (2.5 times higher than methylthio group in the binding assay with G4-DNA telo21). Due to the three-ring-conjugated system is linked through the ethylene bridge that is flexible for free rotation, the increase in structural rigidity could enhance fluorescent signal upon bound with DNA molecule. The telo21 G-quadruplex structure took the advantage as its binding site (the G-quartets) is relatively planar and provides extra hydrogen bond interactions with the dimethylamino groups of $\mathbf{1}$. Previous studies also revealed that the binding affinities obtained with different amino-glycoside ligands for RNA often correlate with the number of amines present in the ligand. ${ }^{24,25}$ Therefore, it is possibly that the dimethylamino groups on the binding ligand could modulate the basicity of the amines and then leads to much stronger interactions with telo21 DNA. Both the 
Table 2 The binding mode and binding energy of the docking study based on the 1 to 1 stoichiometry for 1 and a telomeric G4 DNA (4DA3)

Binding mode \& binding energy Docking poses

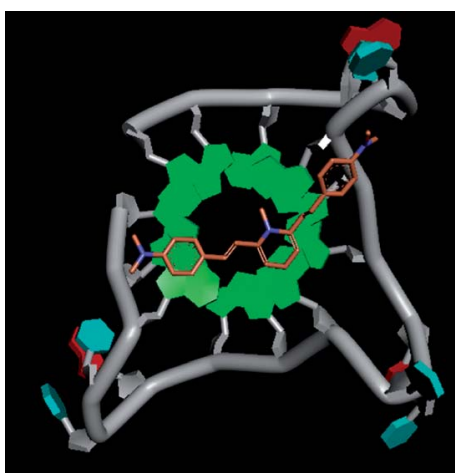

Mode 1: $-6.2 \mathrm{kcal} \mathrm{mol}^{-1}$

Mode 2: $-6.2 \mathrm{kcal} \mathrm{mol}^{-1}$

Mode 3: $-6.2 \mathrm{kcal} \mathrm{mol}^{-1}$
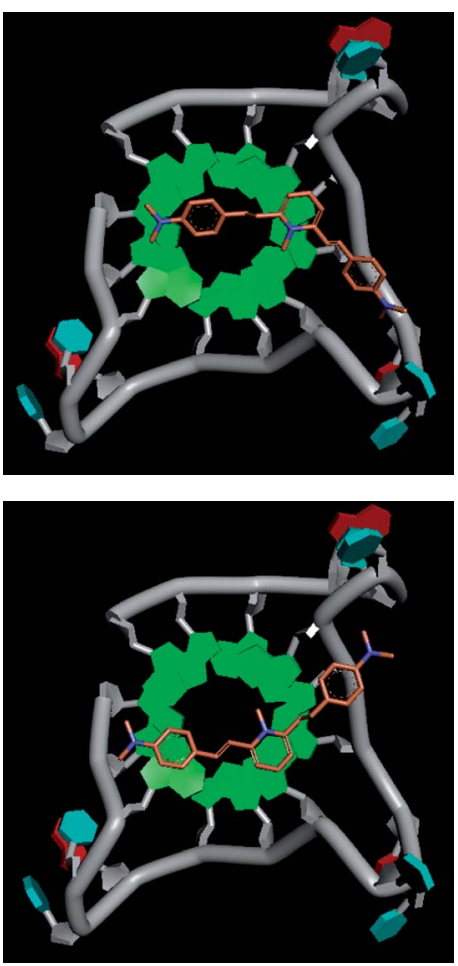

Mode 5: $-6.1 \mathrm{kcal} \mathrm{mol}^{-1}$

Binding mode \& binding energy Docking poses

Mode 4: $-6.2 \mathrm{kcal} \mathrm{mol}^{-1}$
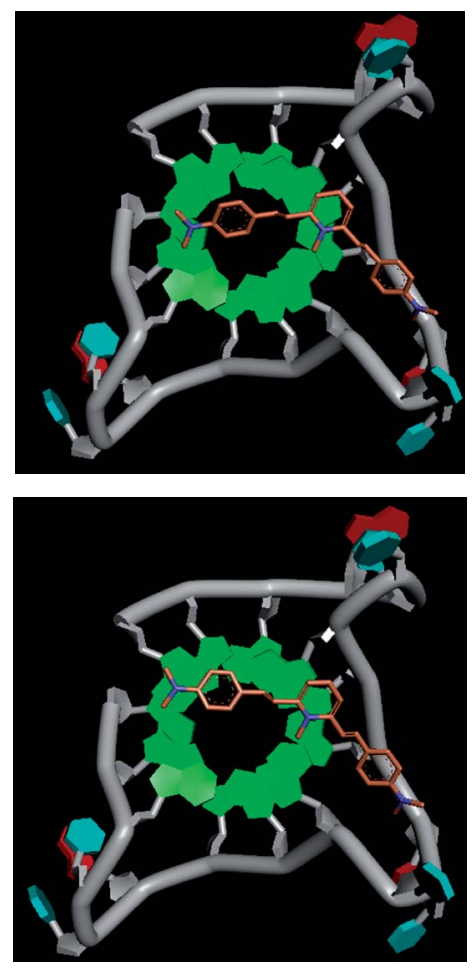

fluorescent quantum yield upon binding with telo21 and the binding affinity of the ligand with dimethylamino groups is better than methylthio group (Table 1). The equilibrium binding constant for the dimethylamino groups is $1.44 \times 10^{5}$ $\mathrm{M}^{-1}$ while for the methylthio groups is significant lower $(1.18 \times$ $\left.10^{5} \mathrm{M}^{-1}\right)$. In addition, a good linear relationship $\left(R^{2}=0.9974\right)$ of the enhanced fluorescent signal of 1 with respect to telo21 DNA concentration in buffer solution ( $\mathrm{pH}$ 7.4) was established (Fig. 3C) and the limit of detection (LOD) in the titration assay for telo21 DNA was estimated to be $5.8 \mathrm{nM}$.

To obtain more information about the interaction property difference due to the side groups of ligand $\mathbf{1}$ and $\mathbf{2}$, the stabilization ability of the ligand bound with G-quadruplex (F21T) and duplex DNA (F10T) was investigated using fluorescence resonance energy transfer (FRET) melting assays. From Fig. 4, as indicated by the $\Delta T_{\mathrm{m}}$ values, both ligands provide much better stabilization ability to G-quadruplex DNA than duplex DNA. However, a larger $\Delta T_{\mathrm{m}}$ value increased by $5{ }^{\circ} \mathrm{C}$ was achieved with ligand 1 (at $2.0 \mu \mathrm{M}$ ) under the same conditions compared with 2 . The result may suggest that the better molecular interactions of $\mathbf{1}$ with G-quadruplex (F21T) is a consequence of the dimethylamino group that provides extra hydrogen bond interactions while the non-polar methylthio group does not offer. In addition, ligand 1 could be a promising human telo21 G-quadruplex stabilizer.

Molecular docking was performed to investigate the binding mode of compound 1 with telomeric G4. The crystal structure of human telomeric DNA G-quadruplex (4DA3) ${ }^{28}$ were used as a template and the result is depicted in Fig. 5. The compound is able to stack onto the G-quartets via pi-pi stacking interactions. The methylated pyridine ring of the compound carrying a positive charge was found to sit closely on the negatively charged 


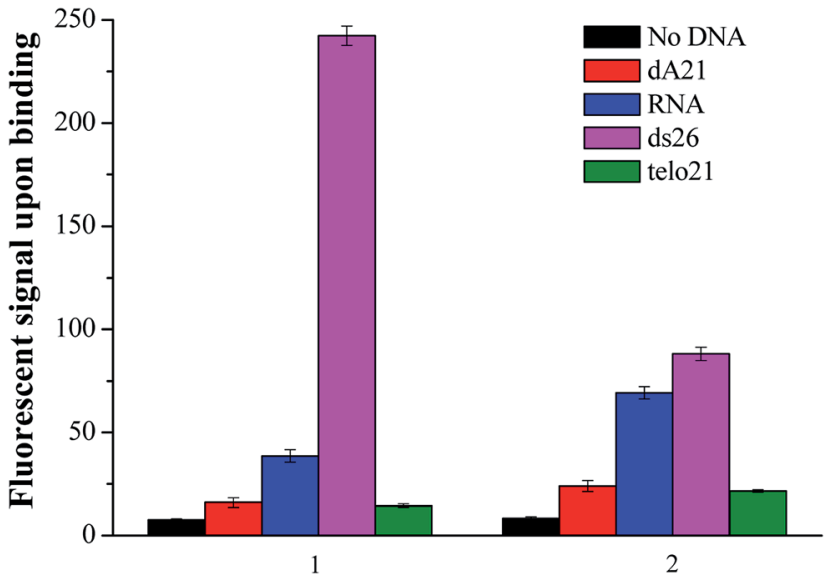

Fig. 2 (A) A comparison of side group effects of the binding ligand: $1 \mathrm{R}$ $=\mathrm{N}\left(\mathrm{CH}_{3}\right)_{2}$ and $2 \mathrm{R}=\mathrm{SCH}_{3}$ in the recognition and sensing of different nucleic acids including single-stand DNA dA21, duplex DNA ds26, Gquadruplex DNA telo21, and RNA. The concentration of the ligand was fixed at $5 \mu \mathrm{M}$.

carbonyl channel to enhance electrostatic interaction with G4. The three-ring system of $\mathbf{1}$ interacts with at least two guanines and the amino functional group of compound is likely to form water mediated H-bonds with $\mathrm{G} 4$ as evidenced by a number of crystal structures of ligand-G4 complex (e.g., PDB ID: 1L1H, 3CE5, 3CDM), where the ligands possesses amino functional groups. All those interactions with G-quartets constrain the $\pi$ conjugation system of $\mathbf{1}$ to a more planar conformation as compared to its unbound form, which is conformational flexible due to the ethylene bridge. ${ }^{22}$ The docking result explains the experimental observation that the ligand system showed weak fluorescent signal in aqueous or physiological conditions while exhibited strong fluorescent signal induction upon binding to telo21 G-quadruplex structure. Interestingly, our findings based on both experimental and docking results are in accord with to previously reported results that the introduction of a net positive charge onto the side chain (through the nitrogen atom of the terminal morpholino moiety) of a series of fluorenone carboxamides can improve G-quadruplex binding (docking study based on 2HY9, a NMR optimized DNA Gquadruplex model GRID MIFs, related to the telomeric sequence d[AG3(T2AG3) $\left.\left.)_{3}\right]\right)^{29}$

In addition, in the docking study based on the 1 to 1 stoichiometry ratio for the ligand interacts with telomeric Gquarduplex using autodock vina. The end stacking interaction with G-quartet is more likely the case because $\mathbf{1}$ is consisted of three aromatic rings connected by a conjugated system and the results show that 1 prefers to stack on $3^{\prime}$ end of the Gquadruplex. All these end stacking poses found from docking study are with $3^{\prime}$ end as listed in Table 2 for comparison.

\section{Conclusions}

In conclusion, a new symmetric ligand with a $N$-methylpyridinium scaffold as the molecular core fused $p$-(dimethylamino) benzyl groups through an ethylene bridge to form a three-ringconjugated system exhibited very weak background emission in
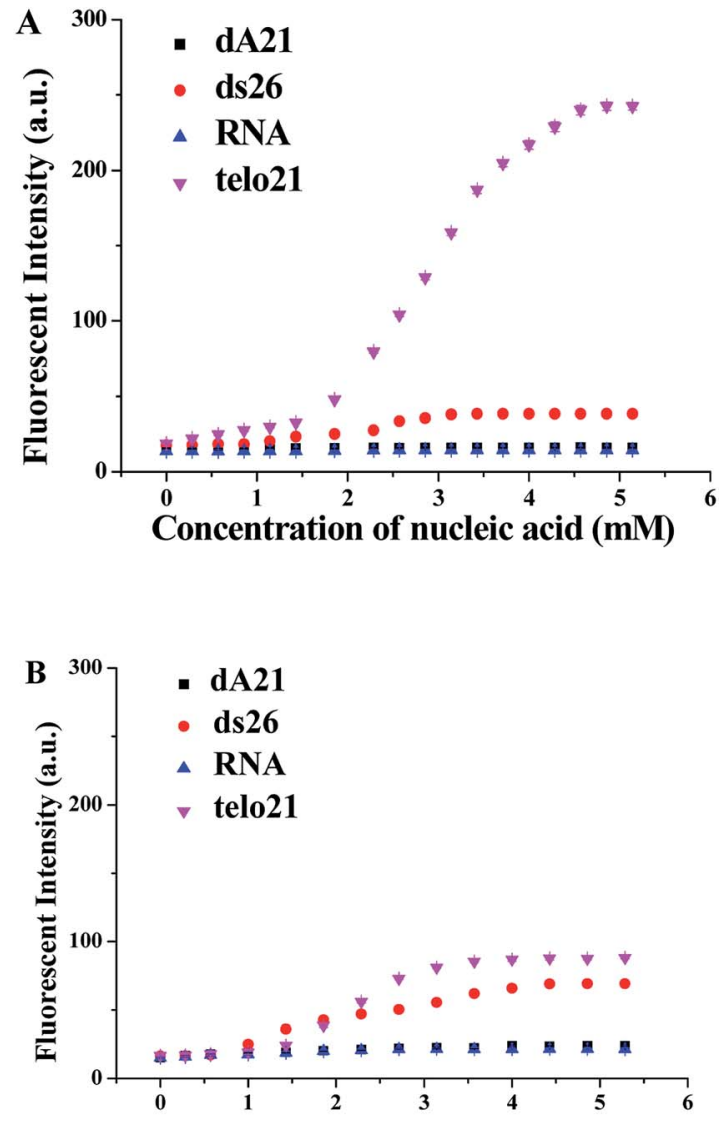

Concentration of nucleic acid (mM)

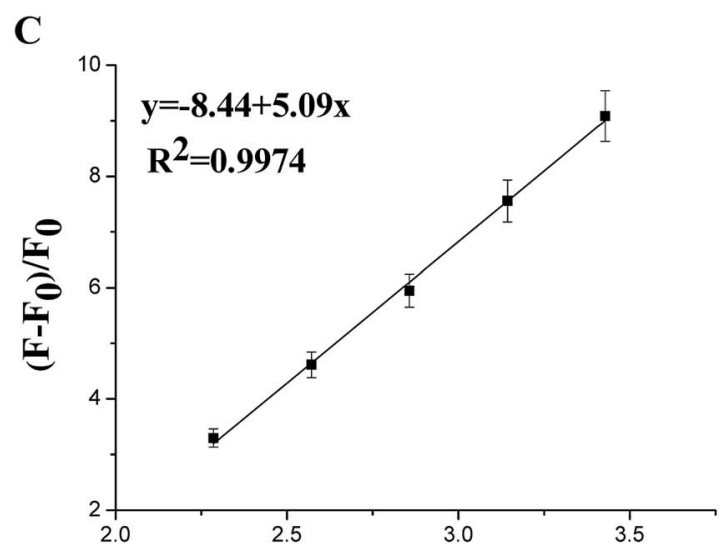

Concentration of telo21 (mM)

Fig. 3 Fluorescence titration experiments for binding kinetics study with different amounts of nucleic acids including single-stand DNA: dA21, duplex-stand DNA: ds26, G-quadruplex DNA: telo21, and RNA; the concentration of 1 and 2 were fixed $5 \mu \mathrm{M}$ in a Tris- $\mathrm{HCl}$ buffer containing $60 \mathrm{mM} \mathrm{KCl}$. (A) Ligand 1, (B) ligand 2, (C) linear relationship of 1 response to the concentration of telo21 in buffer solution and its limit of detection (LOD) value was found to be $5.8 \mathrm{nM}$.

the yellow-green region under physiological conditions. The comparison studies demonstrated that the dimethylamino functional groups showed critical influence on the remarkable induction of fluorescent signal specific to telo21 G-quadruplex structure rather than other type of nucleic acids. 


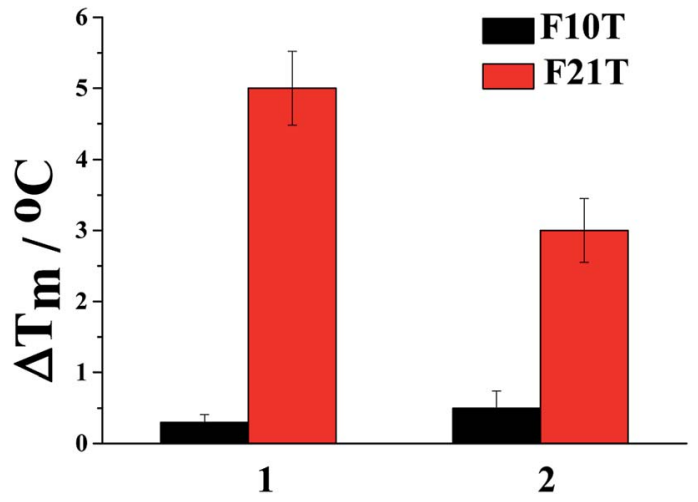

Fig. 4 A bar diagram representation of stabilization of ligand 1 and 2 in FRET-melting assay.

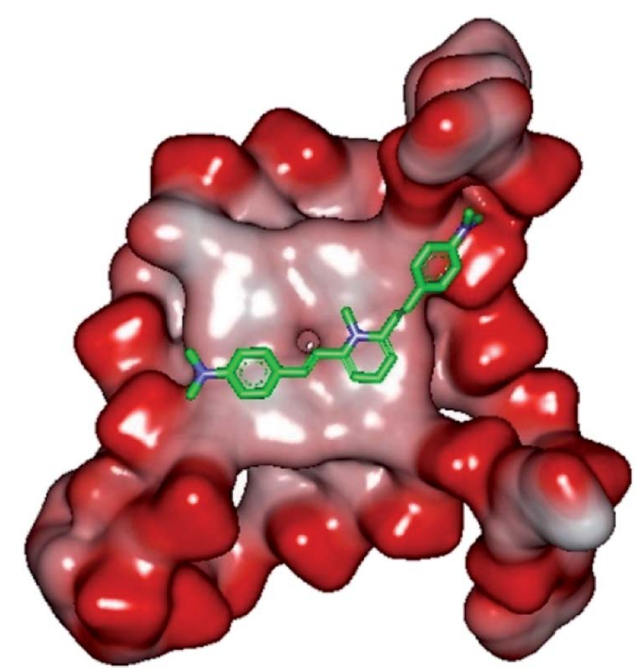

Fig. 5 Molecular docking of 1 with a telomeric G4 (4DA3) to understand the binding mode.

\section{Experimental section}

\section{General information}

All commercial chemicals, reagents, and solvents were analytical grade and were used without further purification. Melting points (mp) measurements were performed using a SRS Opti Mel automated melting point instrument without correction. Mass spectra (MS) were recorded on Bruker amaZon SL mass spectrometer with an ESI or ACPI mass selective detector. ${ }^{1} \mathrm{H}$ and ${ }^{13} \mathrm{C}$ NMR spectra were recorded using TMS as the internal standard in $\mathrm{CDCl}_{3}$ or DMSO with a Bruker BioSpin $\mathrm{GmbH}$ spectrometer at $400 \mathrm{MHz}$ and 100 $\mathrm{MHz}$, respectively. All chemicals were purchased from commercial sources unless otherwise specified. All oligonucleotides used in this work were synthesized and purified by Shanghai Sangon Biotechnology Co., Ltd. (Shanghai, China), and their sequences were as follows: dA21 (single-stranded DNA): AAAAAAAAAAAAAAAAAAAAA; ds26 (duplex DNA): CAATCGGATCGAATTCGATCCGATTG; telo21 (G-quadruplex DNA): GGGTTAGGgTtAGgGTTAGGG; RNA (duplex): 16S- and 23S-Ribosomal from $E$. coli. The fluorescent titration measurements were repeated three times and the averaged values were reported.

\section{Synthesis of 1,2,6-trimethylpyridin-1-ium iodide}

The reaction conditions were followed the reported literature. ${ }^{26}$ 2,6-Dimethylpyridine $(0.22 \mathrm{~g}, 2.05 \mathrm{mmol})$ and iodomethane $(0.50 \mathrm{~g}, 3.52 \mathrm{mmol})$ were added into sulfolane $(0.80 \mathrm{ml})$ at reflux conditions $\left(50{ }^{\circ} \mathrm{C}\right)$ for $4 \mathrm{~h}$. After cooling in an iced bath, the precipitate was filtrated, collected and rinsed with ethyl acetate. The solid was purified by using column chromatography to afford the compound in 95\% yields. Mp 190-192 ${ }^{\circ} \mathrm{C} ;{ }^{1} \mathrm{H}$ NMR (400 MHz, DMSO): $\delta 8.30(\mathrm{t}, J=7.9 \mathrm{~Hz}, 1 \mathrm{H}), 7.90(\mathrm{~d}, J=7.9 \mathrm{~Hz}$, $2 \mathrm{H}), 4.00(\mathrm{~s}, 3 \mathrm{H}), 2.80(\mathrm{~s}, 6 \mathrm{H})$.

\section{General procedures for the synthesis of ligands 1 and 2}

1,2,6-trimethylpyridin-1-ium iodide $(0.53 \mathrm{~g}, 2.2 \mathrm{mmol})$ was reacted with 2.1 equivalents of $p$-(dimethylamino)benzaldehyde or $p$-(methylthio)benzaldehyde in $15 \mathrm{ml} n$-butanol using $0.3 \mathrm{ml}$ 4-methylpiperidine as the base under reflux conditions for $2 \mathrm{~h}$. After reaction, the mixture was cooled in an iced bath. The precipitate was filtrated and then washed twice with $n$-butanol. The collected solids were purified by re-crystallization in acetone to afford the pure compounds. The detailed characterization data were shown as follows:

2,6-Bis((E)-4-(dimethylamino)styryl)-1-methylpyridin-1-ium iodide (1). Brown solid; yield $=70 \%$; $\mathrm{mp} 213-215{ }^{\circ} \mathrm{C} ;{ }^{1} \mathrm{H}$ NMR (400 MHz, DMSO): $\delta 8.20(\mathrm{~d}, J=8.0 \mathrm{~Hz}, 1 \mathrm{H}), 8.08(\mathrm{~d}, J=8.1 \mathrm{~Hz}$, $2 \mathrm{H}), 7.70(\mathrm{~d}, J=8.9 \mathrm{~Hz}, 5 \mathrm{H}), 7.66(\mathrm{~s}, 1 \mathrm{H}), 7.31(\mathrm{~d}, J=15.7 \mathrm{~Hz}$, $2 \mathrm{H}), 6.79$ (d, $J=9.0 \mathrm{~Hz}, 4 \mathrm{H}), 4.19(\mathrm{~s}, 3 \mathrm{H}), 3.03(\mathrm{~s}, 12 \mathrm{H}) .{ }^{13} \mathrm{C}$ NMR (100 MHz, DMSO) $\delta$ 154.10, 152.26, 143.25, 141.87, $130.78,123.07,121.63,113.30,112.24,41.47$. HRMS $m / z$ : $384.2421[\mathrm{M}-\mathrm{I}]^{+}$.

1-Methyl-2,6-bis((E)-4-(methylthio)styryl)pyridin-1-ium iodide (2). Orange solid; yield $=85 \%$; mp $203-205{ }^{\circ} \mathrm{C} ;{ }^{1} \mathrm{H}$ NMR $(400$ MHz, DMSO): $\delta 8.41(\mathrm{t}, J=8.1 \mathrm{~Hz}, 1 \mathrm{H}), 8.26(\mathrm{~d}, J=8.1 \mathrm{~Hz}, 2 \mathrm{H})$, $7.82(\mathrm{~d}, J=8.5 \mathrm{~Hz}, 4 \mathrm{H}), 7.76(\mathrm{~d}, J=15.9 \mathrm{~Hz}, 2 \mathrm{H}), 7.64(\mathrm{~d}, J=$ $15.9 \mathrm{~Hz}, 2 \mathrm{H}), 7.37$ (d, $J=8.5 \mathrm{~Hz}, 4 \mathrm{H}), 4.29(\mathrm{~s}, 3 \mathrm{H}), 2.55(\mathrm{~s}, 6 \mathrm{H}) .{ }^{13} \mathrm{C}$ NMR (100 MHz, DMSO): $\delta$ 153.82, 143.27, 142.36, 131.95, 129.43, $126.13,124.01,118.45,42.14,14.74$. HRMS $m / z: 390.1335$ [M $\mathrm{I}]^{+}$.

\section{FRET assay}

The FRET assay was performed as a high-throughput screen following previously published procedures. ${ }^{27}$ The labeled oligonucleotides F21T: $5^{\prime}$-FAM-d(GGG[TTAGGG] $]_{3}$ )-TAMRA-3' (donor fluorophore FAM is 6-carboxyfluorescein; acceptor fluorophore TAMRA is 6-carboxytetramethylrhodamine; HEG linker is $\left.\left[\left(-\mathrm{CH}_{2}-\mathrm{CH}_{2}-\mathrm{O}-\right)_{6}\right]\right)$ used as the FRET probes were diluted from stock to the correct concentration $(0.4 \mu \mathrm{M})$ in buffer and then annealed by heating to $95{ }^{\circ} \mathrm{C}$ for $5 \mathrm{~min}$, followed by cooling to room temperature. Samples were prepared by aliquoting 15 $\mu \mathrm{L}$ of the annealed F21T (at $2 \times$ concentration, $0.4 \mu \mathrm{M}$ ) into LightCycler 96 , followed by $15 \mu \mathrm{L}$ of the ligand solution (at $2 \times$ concentration, 0.2-2.0 $\mu \mathrm{M}$ ) and further incubated for $1 \mathrm{~h}$. Fluorescence melting curves were determined with a Roche 
LightCycler real-time PCR machine with excitation at $470 \mathrm{~nm}$ and detection at $530 \mathrm{~nm}$. Fluorescence readings were taken at intervals of $3{ }^{\circ} \mathrm{C}$ over the range $37-93{ }^{\circ} \mathrm{C}$, with a constant temperature being maintained for $300 \mathrm{~s}$ prior to each reading to ensure a stable value.

\section{Molecular docking study}

The crystal structure of human telomeric DNA G-quadruplex $(4 \mathrm{DA} 3)^{28}$ were used as a template to perform docking study on compound 1. The 3D structures of the small molecules were sketched using DS viewer 3.5. Autodock Tools (ver. 1.5.6) was used to convert the structure files to pdbqt format. ${ }^{30}$ Docking calculation was performed using the AUTODOCK vina program. ${ }^{31}$ The dimensions of the active site box were chosen to be large enough to encompass the entire G4 structures. An exhaustiveness of 100 was used and other parameters were left as default.

\section{Conflicts of interest}

There are no conflicts to declare.

\section{Acknowledgements}

We acknowledge the support received from the National Nature Science Foundation of China (21102021 and 81473082), Nature Science Foundation of Guangdong Province, China (2017A030313078), Science and Technology Program of Guangdong Province (2012B020306007), and the Department of Education Guangdong Province (No. 2016KCXTD005, 2017KSYS010).

\section{Notes and references}

1 A. T. Aron, K. M. Ramos-Torres, J. A. Cotruvo Jr and C. J. Chang, Acc. Chem. Res., 2015, 48(8), 2434-2442.

2 M. C. Heffern, H. M. Park, H. Y. Au-Yeung, G. C. V. Bittner, C. M. Ackerman, A. Stahl and C. J. Chang, Proc. Natl. Acad. Sci., 2016, 113(50), 14219-14224.

3 P. S. Zhang, H. Wang, Y. X. Hong, M. L. Yu, R. G. Zeng, Y. F. Long and J. Chen, Biosens. Bioelectron., 2018, 318-324.

4 J. L. Kolanowski, F. Liu and E. J. New, Chem. Soc. Rev., 2018, 47(1), 195-208.

5 M. J. Lohse, S. Nuber and C. Hoffmann, Pharmacol. Rev., 2012, 64(2), 299-336.

6 R. Y. Tsien, Annu. Rev. Neurosci., 1989, 12, 227-253.

7 T. Terai and T. Nagano, Pflügers Arch., 2013, 465(3), 347-359.

8 M. Maekawa and G. D. Fairn, J. Cell Sci., 2014, 127, 48014812.

9 X.-P. He and H. Tian, Chem, 2018, 4, 246-268.
10 X. Su, X. J. Xiao, C. Zhang and M. P. Zhao, Appl. Spectrosc., 2012, 66(11), 1249-1261.

11 D. J. Stephens and V. J. Allan, Science, 2003, 300(5616), 8286.

12 A. Shivanandan, H. Deschout, M. Scarselli and A. Radenovic, FEBS Lett., 2014, 588, 3595-3602.

13 S. Cox, Dev. Biol., 2015, 401, 175-181.

14 S. Ray, J. R. Widom and N. G. Walter, Chem. Rev., 2018, 118 (8), 4120-4155.

15 A. C. Bhasikuttan and J. Mohanty, Chem. Commun., 2015, 51, 7581-7597.

16 A. Laguerre, K. Hukezalie, P. Winckler, F. Katranji, G. Chanteloup, M. Pirrotta, J.-M. Perrier-Cornet, J. M. Y. Wong and D. Monchaud, J. Am. Chem. Soc., 2015, 137, 8521-8525.

17 Y. V. Suseela, N. Narayanaswamy, S. Pratihar and T. Govindaraju, Chem. Soc. Rev., 2018, 47, 1098-1131.

18 M.-Q. Wang, Y. Wu, Z.-Y. Wang, Q.-Y. Chen, F.-Y. Xiao and Y.-C. Jiang, Dyes Pigm., 2017, 145, 1-6.

19 B. R. Vummidi, J. Alzeer and N. W. Luedtke, ChemBioChem, 2013, 14(5), 540-558.

20 L. Y. Zhang, J. Cheng, K. K. Ghosh, W. J. Chung, J. Yoo, W. Xu, W. Zhao, A. T. Phan and Y.-T. Chang, Sci. Rep., 2014, 4, 3776.

21 A. Shivalingam, M. A. Izquierdo, A. L. Marois, A. Vyšniauskas, K. Suhling, M. K. Kuimova and R. Vilar, Nat. Commun., 2015, 6, 8178.

22 N. Sun, C. Wang, M.-H. Xu, Y.-J. Lu, Y.-Y. Zheng and Y. Yan, Sens. Actuators, B, 2017, 250, 543-551.

23 Y.-J. Lu, Q. Deng, J.-Q. Hou, D.-P. Hu, Z.-Y. Wang and K. Zhang, ACS Chem. Biol., 2016, 11, 1019-1029.

24 C. H. Wong, M. Hendrix, E. S. Priestley and W. A. Greenberg, Chem. Biol., 1998, 5, 397-406.

25 J. A. Means and J. V. Hines, Bioorg. Med. Chem. Lett., 2005, 15, 2169-2172.

26 Y.-J. Lu, D.-P. Hu, Q. Deng, Z.-Y. Wang, B.-H. Huang, Y.-X. Fang, K. Zhang and W.-L. Wong, Analyst, 2015, 140, 5998-6004.

27 X. Xie, A. Renvoise, A. Granzhan and M. P. Teulade-Fichou, New J. Chem., 2015, 39, 5931-5935.

28 M. Micco, G. W. Collie, A. G. Dale, S. A. Ohnmacht, I. Pazitna, M. Gunaratnam, A. P. Reszka and S. Neidle, J. Med. Chem., 2013, 56, 2959-2974.

29 S. Alcaro, A. Artese, J. N. Iley, S. Missailidis, F. Ortuso, L. Parrotta, R. Pasceri, F. Paduano, C. Sissi, F. Trapasso and M. G. Vigorita, ChemMedChem, 2010, 5, 575-583.

30 G. Morris and R. Huey, J. Comput. Chem., 2009, 30, 27852791.

31 S. Forli, R. Huey, M. E. Pique, M. F. Sanner, D. S. Goodsell and A. J. Olson, Nat. Protoc., 2016, 11, 905-9012. 